\title{
Verónica Leuci, Poetas in-versos. Ficción y nombre propio en Gloria Fuertes y Ángel González, Villa María, Eduvim, 2018, 204 páginas.
}

\author{
Mariana Wind \\ Universidad Nacional de Mar del Plata, Argentina
}

Cita sugerida: Wind, M. (2019). [Revisión del libro Poetas in-versos. Ficción y nombre propio en Gloria Fuertes y Ángel González por V. Leuci]. Olivar, 20(31), e078. https://doi.org/10.24215/18524478e078

Poetas in-versos es un estudio sobre la obra poética de Ángel González y Gloria Fuertes. Su autora, Verónica Leuci -integrante del grupo de investigación "Semiótica del discurso", del Centro de Letras Hispanoamericanas de la Universidad Nacional de Mar del Plata- propone una lectura que tiene como eje la incorporación poética de nombres propios y guiños biográficos. A lo largo de diez capítulos -cinco para cada autor- analiza la operatividad del concepto de autoficción en los dos poetas de la España de posguerra.

El libro comienza con una introducción en la cual la autora repasa una serie de conceptos y definiciones que resultan fundamentales para el análisis: la lectura de la tensión entre el carácter verbal y las referencias biográficas a la luz de la categoría de "autoficción”. Esta noción, -que retoma del trabajo del crítico español Manuel Alberca- será la clave que articule el estudio de las dos poéticas que la ocupan. Además, presenta la categoría de "espacio autoficcional" para referirse a una zona textual y paratextual signada por los indicios autobiográficos y referenciales, y examina algunos antecedentes de la tradición de la autonominación en la poesía universal.

La primera parte del libro se denomina "En carne y verso: identidades poéticas y nombres propios en Gloria Fuertes". A lo largo de cinco capítulos, Leuci rastrea las distintas estrategias escriturarias tendientes a crear una "atmósfera autobiográfica" en toda la producción literaria de la autora. El primero, "Miradas críticas, filiaciones literarias y figuraciones (auto)poéticas" abre con un repaso por la crítica previa sobre la obra de Fuertes, para constatar la marginalidad de esta escritora en el panorama de la crítica especializada, pese a la popularidad de su figura en otros ámbitos (radio, televisión, prensa). Más adelante, se centra en 
la construcción del sujeto autoficcional en la tensión entre biografía y ficción, haciendo hincapié en la constitución de una identidad multifacética marcada por su género -con las vicisitudes de ser una poeta mujer en el horizonte de la poesía española de posguerra- y por un carácter claramente popular, en relación con la sencillez retórica de su escritura, destinada especialmente a los sectores más humildes de la sociedad.

Los capítulos dos y tres se ocupan de estudiar la inclusión del nombre propio en sus poemas. En "El nombre de autor como correlato autoral: contorsiones gramaticales", Leuci indaga, mediante el análisis de numerosos ejemplos tomados de los poemarios de Fuertes, en los modos en que la autora juega con las personas gramaticales y los usos sintácticos para situarse en sus versos como poeta y como personaje. Por otro lado, en "Juegos polisémicos con el nombre propio: Gloria y Fuertes" se centra en el examen de las maneras en que la poeta utiliza el valor semántico de las palabras que conforman su nombre y apellido. Apoyándose nuevamente en el análisis textual, hace un exhaustivo repaso de las figuras retóricas -principalmente la dilogía y la diáfora- que afianzan la polisemia y el equívoco.

La forma en que Gloria Fuertes incorpora en su poesía otros personajes que en ocasiones “absorben” la voz del hablante poético es el tema del cuarto capítulo: "El universo polifónico: voces, hablantes e identidades poéticas". Aquí, la investigadora se aboca al estudio de los procedimientos que le permiten a la poeta incluir las voces de personajes de extracción popular, muchas veces marginales: prostitutas, menesterosos, vendedores ambulantes, pregoneros, entre otros. El principal recurso examinado es el monólogo dramático, caracterizado por la inclusión de un personaje hablante -distinto del yo autoral- que se constituye en persona dramática en tanto tiene un interlocutor que interviene de forma indirecta.

Finalmente, el último capítulo de la primera parte, “Autobio: retratos fragmentarios”, profundiza en las formas de constitución del sujeto autoficcional a través de la serie de treinta y nueve poemas diseminados a lo largo de su obra con ese nombre, Autobio. Por un lado, se centra en los paratextos -fotografías de la autora, títulos, subtítulos, epígrafe- para reconstruir un itinerario del "espacio autoficcional” que la poeta crea en sus obras. Por otro, se desbroza lo que Leuci considera los tres núcleos centrales que conforman la subjetividad autoficcional de Gloria Fuertes: la carencia, en relación con la pobreza, como también con la soledad y el desamor; la pertenencia genérica al universo de lo femenino; y su vocación de poeta comprometida.

Hacia la mitad del volumen, se abre la segunda parte del estudio: “'Verse en el verso': usos del nombre propio en Ángel González”, dedicada a la obra del poeta ovetense. El primer capítulo, “Tiempo, identidad y poesía: el triple canto del "medio siglo"' sitúa primeramente al autor en su contexto sociohistórico -los primeros tiempos de la dictadura franquista-, y en la historia literaria española- es decir, la denominada Generación del '50- para poder abocarse después al examen de la construcción identitaria de González en sus versos, a través de procedimientos tales como la ironía y el desdoblamiento del yo.

En el capítulo "Desplazamientos metapoéticos del nombre de autor", la autora retoma los episodios biográficos de la historia de González que selecciona Luis García Montero para el prólogo de la Antología poética (2004), con el fin de proyectarse hacia los distintos usos del nombre propio y observar cómo estas experiencias de la realidad se convierten en un personaje poético. Asimismo, se delimitan tres momentos de la poesía gonzaliana: una primera parte, más abocada a la poesía social y testimonial; un segundo momento de escepticismo respecto de la posibilidad de "cambiar el mundo" con la literatura; y la etapa de senectud, caracterizada por el tono elegíaco y meditativo. Este itinerario tiende fundamentalmente a observar la caracterización del sujeto poético en cada uno de esos momentos.

"Cartografías poéticas: geografías vitales” es el título del tercer capítulo, que se ocupa de reconstruir una matriz de poesía esencialmente urbana. La autora analiza aquí, por un lado, la tendencia a la recreación de una ciudad moderna innominada, anónima, que constituye una crítica de la globalización y sus efectos; y por otro, la utilización de topónimos -Oviedo, Madrid, Albuquerque- que dan cuenta de una trayectoria geográfica que aporta a la creación de una atmósfera autoficcional, no sólo por remitir a la realidad vital del poeta, sino también porque los nombres de estas ciudades funcionan como marcadores temporales, vinculados con distintas etapas de la vida del autor. 
Los modos en que Ángel González se introduce a sí mismo en una tradición poética, son el tema del penúltimo capítulo, "Homenajes, tradiciones, genealogías: elecciones onomásticas en la trayectoria poética". En este apartado, Leuci observa el modo en que el poeta diseña una tradición propia, no sólo a través de su producción ensayística, sino especialmente en la esfera intertextual. Así, se aboca a reconstruir una genealogía a partir de los nombres de otros autores que aparecen en sus textos y paratextos -Juan Ramón Giménez, Stéphane Mallarmé, Blas de Otero, Jorge Guillén, Claudio Rodríguez, Antonio Machado, entre otros- y con los cuales establece un diálogo que va desde el homenaje a la parodia.

Por último, el capítulo "Importaciones vitales: acotaciones biográficas" se detiene en las pautas de escritura que, de forma manifiesta, imprimen un carácter autoficcional de los poemas. Por esto, profundiza en el estudio de algunos textos y paratextos que aluden explícitamente al universo autobiográfico: el título Breves acotaciones para una biografía (1971), algunos paratextos de la sección "Biografías e historias", del libro Prosemas o menos y los títulos de tres poemas, "Dato biográfico", "Autorretrato de los sesenta años" y "El poema de los 82 años". La autora lee el corpus en clave autoficcional y cataloga algunos de los procedimientos y estrategias utilizados por González para generar extrañamiento en sus lectores, tales como la inversión de las estructuras sintácticas y el uso de asociaciones semánticas inesperadas.

A modo de conclusión, el libro culmina con el apartado "Tras los ecos de un nombre", que apunta, por un lado, hacia la productividad de la categoría de autoficción dentro del pensamiento crítico posmoderno; y por otro, remarca cómo los dos poetas estudiados, a través de estrategias distintas, pero con puntos en común, conforman unas imágenes autorales que ponen continuamente en cuestión las aristas desideologizadas y ahistóricas de la posmodernidad.

Poetas in-versos resulta un aporte valioso para la crítica poética. En primer lugar, resulta interesante el exhaustivo trabajo de análisis discursivo, especialmente en el caso de Gloria Fuertes, una poeta poco abordada por la crítica especializada. Por otra parte, es innovadora la forma en que explota la productividad crítica de la categoría de autoficción para observar su operatividad en la interpretación de textos poéticos. Y, por último, la introducción de las categorías de "sujeto autoficcional” y "espacio autoficcional" se constituye como una contribución significativa para quienes se aboquen al estudio de lo que anteriormente se denominó "poesía autobiográfica”. 